\title{
Survival of Escherichia coli in Beef Cattle Fecal Pats Under Different Levels of Solar Exposure
}

\author{
Cindy L. Meays, ${ }^{1}$ Klaas Broersma, ${ }^{2}$ Rick Nordin, ${ }^{3}$ \\ and Asit Mazumder ${ }^{4}$
}

\begin{abstract}
Authors are ${ }^{1} \mathrm{PhD}$ Candidate, Department of Biology, National Science and Engineering Research Council Industry Research Chair (NSERC/IRC) Environmental Management of Drinking Water, University of Victoria, Victoria, BC, V8N 3N5, Canada; ${ }^{2}$ Soil Scientist, Agriculture and Agri-Food Canada, Kamloops, BC, V2B 8A9, Canada; ${ }^{3}$ Senior Research Scientist, Department of Biology, NSERC/IRC Environmental Management of Drinking Water, University of Victoria, Victoria, BC, V8N 3N5, Canada;

${ }^{4}$ NSERC/IRC Chair and Professor, Department of Biology, NSERC/IRC Environmental Management of Drinking Water,
\end{abstract} University of Victoria, Victoria, BC, V8N 3N5, Canada.

\begin{abstract}
Understanding the survival and transport of Escherichia coli in feces on land and in water is important when trying to assess contamination of water by grazing animals. A fecal-pat experiment was conducted in July and August of 2003 to investigate the survival of E. coli under 4 levels of solar exposure controlled by using shade cloth. Fresh beef cattle manure was uniformly blended to produce 2.5 - and $1.6 \mathrm{~kg}$ fecal pats, which were placed in plastic trays or in contact with the soil and covered with $0 \%, 40 \%$, $80 \%$, or $100 \%$ shade cloth treatments and replicated 5 times. Samples from each fecal pat were collected at Time 0 to establish $E$. coli levels; sampling was repeated at Day 1, Day 3, and approximately weekly thereafter for 45 days to determine die-off. E. coli concentration and percent moisture were measured for each fecal sample. At the end of the experiment, fecal pats under the $0 \%$ shade cloth had the lowest $E$. coli concentrations, followed by the $40 \%, 80 \%$, and $100 \%$ treatments, with $0.018,0.040,0.11$, and $0.44 \times 10^{6}$ colony-forming units $(\mathrm{CFU}) \cdot \mathrm{g}^{-1}$, respectively. Fecal-pat size was significant only on Day 17 , when large fecal pats had higher concentrations of $E$. coli $(P<.0001)$. There was no significant difference $(P=0.43)$ in E. coli concentration between the fecal pats in contact with the soil vs. those in plastic trays. Percent moisture of fecal pats was not a good covariate. Age of fecal pats, as well as exposure to solar radiation negatively influences the survival of E. coli. From a management perspective, E. coli in fecal pats under forested situations would survive longer than in open grasslands due to shading, and any possible contamination by E. coli would be greatest within 7 days of removing cattle from a riparian area or pasture.
\end{abstract}

\section{Resumen}

Entender la supervivencia y transporte de E. coli en las heces sobre el tierra y en el agua es importante cuando intentamos evaluar la contaminación del agua por los animales en apacentamiento. En Julio y Agosto del 2003 se condujo un experimento con tortas de heces fecales para investigar la supervivencia del E. coli bajo cuatro niveles de exposición solar controlada usando una tela para sombreado. Estiércol fresco de ganado bovino para carne fue mezclado uniformemente para producir tortas de 2.5 y $1.6 \mathrm{~kg}$, que se colocaron en charolas o en contacto con el suelo bajo tratamientos de $0 \%, 40 \%, 80 \%$, y $100 \%$ de sombreado repetidos cinco veces. Muestras de cada torta fecal se colectaron en el tiempo cero para establecer los niveles de E. coli y en el día uno, día tres y aproximadamente cada semana durante 45 días para determinar la dinámica de mortalidad de la bacteria. La concentración de $E$. coli y humedad se midieron en cada muestreo fecal. Al final del experimento, las tortas fecales bajo $0 \%$ de sombreado tuvieron las menores concentraciones de E. coli, seguida por los tratamientos de $40 \%, 80 \%$, y $100 \%\left(0.018,0.040,0.11\right.$, y $0.44 \times 10^{6}$ unidades formadoras de colonias (CFU) $\cdot \mathrm{g}^{-1}$ respectivamente). El tamaño de la torta fecal fue significativo solo en el día 17 , las tortas fecales mas grandes tuvieron mayores concentraciones de $E$. coli $(P<.0001)$. No hubo diferencia significativa $(P=0.43)$ en la concentración de $E$. coli entre las tortas fecales en contacto con el suelo y las que estaban en las charolas plásticas. El porcentaje de humedad de las tortas fecales no fue una buena covariable. La edad de las tortas fecales, así como la exposición a la radiación solar influyen negativamente en la supervivencia de la E. coli. Desde una perspectiva de manejo, E. coli, en las heces fecales bajo situaciones de áreas arboladas pudiera sobrevivir mas que bajo condiciones de pastizal abierto debido al sombreado y cualquier posibilidad de contaminación por E. coli sería mayor dentro de 7 días después de remover el ganado del área ribereña o potrero.

Key Words: fecal bacteria, water quality, pathogens

Research was funded by British Columbia Beef Cattle Industry Fund; Agriculture and Agri-Food Canada's Matching Investment Initiative; Agriculture Environment Partnership Initiative; North Okanagan Livestock Association; National Science and Engineering Research Council Industry Research Chair Grant; Ministry of Agriculture, Food and Fisheries; and University of Victoria Fellowship.

At the time of research, Meays was a doctoral student, Department of Biology, NSERC/IRC Environmental Management of Drinking Water, University of Victoria, Victoria, BC, Canada.

Correspondence: Cindy Meays, Agriculture and Agri-Food Canada, 3015 Ord Road, Kamloops, BC, V2B 8A9. Email: Meaysc@uvic.ca

Manuscript received 29 April 2004; manuscript accepted 29 November 2004.

\section{INTRODUCTION}

Fecal coliforms and Escherichia coli are used in water quality testing as indicators of fecal contamination and potential pathogens (Rosen 2000). Although these indicators are not usually pathogenic and often don't correlate well with the pathogens that they are meant to indicate, they are easier and less costly to detect and enumerate than are the actual 
pathogens. Fecal contamination of water can come from many sources (wildlife, livestock, and humans). New molecular and biochemical methods for detecting the sources of fecal contamination are being developed (Scott et al. 2002; Simpson et al. 2002; Meays et al. 2004), but information on the survival and growth of bacteria and waterborne pathogens is limiting and often contradictory (Alexander 1986; Park et al. 1991; Ferguson et al. 2003). Microbial contamination of source water is a major environmental and health issue with drinking water in British Columbia (BC), Canada, and worldwide (BC Gov. 2001; WHO 2003). Many people rely on surface water from watersheds with multiple uses (forestry, mining, agriculture, wildlife, urban development, and recreation) as the source of their drinking water. Maintaining sustainable clean water supplies requires sound scientific data on the pollutants that affect water quality. E. coli is probably one of the most studied organisms, but the majority of research has been conducted on pure cultures in the laboratory, or on cultures inoculated into livestock waste (Avery et al. 2004). Park et al. (1991) argued that the survival and optimum conditions for an organism in a laboratory experiment may be very different than what happens under various environmental conditions. Both laboratory and field experiments are needed in order to understand the survival of these organisms.

In a series of field experiments looking at fecal coliforms, Buckhouse and Gifford (1976) and Bohn and Buckhouse (1985) suggested that cattle feces could provide a protective medium for coliforms to survive for at least a year. Buckhouse and Gifford (1976) also concluded that bacteria did not travel farther than $1.0 \mathrm{~m}$ on a sandy loam range site located in southeastern Utah. Doyle et al. (1975) studied forested buffer strips in controlling bacterial transport on a gravelly silt loam soil and observed no significant movement of bacteria beyond $3.8 \mathrm{~m}$. In a laboratory experiment simulating overland flow and bacterial movement across plots, Larsen et al. (1994) found that bacterial loads were reduced by $95 \%$ if $2.13 \mathrm{~m}$ distance between the feces and the collection point for overland flow were maintained. They found that even with a small buffer of $0.61 \mathrm{~m}$ the coliform count was reduced by $83 \%$. More studies are needed to look at E. coli and other fecal pathogens and their movement through soils under different environmental conditions.

Although it is generally thought that there are no significant environmental sources of $E$. coli and other fecal bacteria that are unrelated to direct fecal contamination (Byappanahalli and Fujioka 1998), there have been studies supporting the idea that fecal bacteria can survive and grow in the environment (Gerba and McLeod 1976; Tassoula 1997; Byappanahalli and Fujioka 1998; Topp and Scott 2003; Topp et al. 2003; Unc and Goss 2003). Understanding the potential of fecal bacteria to survive and grow under certain circumstances is critical for managing watersheds or areas that have chronic high fecal counts.

Sunlight is reported to be one of the most detrimental factors to the survival of E. coli in water (Chamberlin and Mitchell 1978; Fujioka et al. 1981), and available water has been suggested as being most critical for E. coli's survival in soils (Unc and Goss 2003). Other factors that have been shown or suggested to influence the survival of bacteria as mentioned above include temperature, $\mathrm{pH}$, nutrients, predators, soil type, season, and competition with other organisms (Chamberlin and Mitchell 1978; Fujioka et al. 1981; Alexander 1986; Sherr et al.
1987; Ferguson et al. 2003; Unc and Goss 2003). There is very little information available on whether the factors influencing microbial survival are the same for aquatic systems, manure, and soil matrices (Ferguson et al. 2003).

A more holistic approach to understanding fecal pollution is needed. Such an approach would identify the sources of fecal pollution and determine the survival and transport of the pathogens on land and in water. Survival and transport of bacteria in the environment is very complex. The objectives of this study were to 1) determine the impact of shade on survival of E. coli, 2) determine if size of fecal pat affects survival of $E$. coli, 3) determine any differences in survival of $E$. coli in contact with soil vs. on plastic trays, and 4) determine if there is a relationship between E. coli survival and the percent moisture of feces at the time of sampling.

\section{MATERIALS AND METHODS}

A fecal-pat experiment was conducted in July and August of 2003 near the town of Armstrong in the south-central interior of $\mathrm{BC}$ to investigate the survival of E. coli under 4 levels of solar exposure controlled by using shade cloth. July and August 2003 broke records for being extremely hot and dry months in the southern interior of $\mathrm{BC}$. The mean average maximum temperatures for July and August 2003 were $30.0^{\circ} \mathrm{C}$ and $31.1^{\circ} \mathrm{C}$, respectively. The temperatures for July and August 2003 were $3.4^{\circ} \mathrm{C}$ and $4.9^{\circ} \mathrm{C}$ above the long-term average. The amounts of precipitation for July and August 2003 were $3.9 \%$ and $4.7 \%$, respectively, of the long-term average for this region.

\section{Field Plots}

Clear plastic tarps ( $0 \%$ direct solar block), ginseng tarps $(40 \%$ and $80 \%$ direct solar block), and reflective, impenetrable, solid, silver-colored tarps (100\% direct solar block), all $1.8 \times 3 \mathrm{~m}^{2}$, were suspended and anchored using metal posts, ropes, and tent pegs to create tent-like structures. Five tarps of each type were draped and centered over each of four $12.5 \mathrm{~m}$ ropes (total of 20 tarps) and anchored approximately $0.3 \mathrm{~m}$ above the ground using tent pegs and rope to allow for air circulation. Spacing between the tarps was approximately $0.6 \mathrm{~m}$. The 5 replicates of $0 \%, 40 \%, 80 \%$, and $100 \%$ shade were completely randomized in the field.

\section{Source of $E$. coli}

Natural populations of E. coli in fresh beef cattle manure were used for this experiment. Approximately $200 \mathrm{~kg}$ of fresh beef cattle manure was collected from 2 ranches using shovels and pails. Cattle manure was transported to the field plot site using 4 large plastic garbage cans. Manure was emptied from the garbage cans into a clean Rubbermaid ${ }^{\circledR} 450-\mathrm{L}$ water trough and blended thoroughly using a drywall mud paddle attached to an electric drill. Fecal pats $(2.5 \mathrm{~kg}$ and $1.6 \mathrm{~kg}$ wet weight $)$ were made from the uniformly blended manure. Each size fecal pat was placed both directly on the ground as well as in pie-shaped plastic trays for a total of 4 fecal pats under each of the 20 tarps. The location of both the shade tarps as well as the location of the fecal pats under the tarps was completely randomized. 


\section{Sampling}

Five replicate samples of blended fresh manure were collected and cultured to establish the initial E. coli concentration of the fresh manure at Time 0 . Samples of approximately $1-2 \mathrm{~g}$ were taken from each fecal pat on Days 1,3, and 7, and approximately weekly thereafter for 45 days to determine viable $E$. coli concentrations. Samples were taken from the middle of the fecal pat and transported to the laboratory in sterile, individually labeled vials in a picnic cooler with ice. Additional measurements included the percent moisture of feces at each sampling time and hourly measurements of fecal-pat temperature, air temperature, and ground temperature using Onset $\mathrm{HOBOS}^{\circledR}$ and Tidbits ${ }^{\circledR}$.

\section{Plating and Enumerating}

Samples were collected from fecal pats and taken on ice directly to the laboratory for culturing. Measuring spoons and spatulas were flame-sterilized before and between each fecal sample. A 1 -mL volume of fecal material was added to $90 \mathrm{~mL}$ of sterilized deionized water. The same amount was put in the incubator to calculate percent moisture. The determined dry weight of the fecal material was used in the calculation of E. coli concentrations per dry-weight gram of sample. The bottles containing the water and fecal samples were vigorously shaken to suspend E. coli. The water samples were then placed in a walk-in cooler (approximately $4^{\circ} \mathrm{C}$ ) for approximately 2 hours until they were filtered. Bottles were inverted 10 times prior to filtration using the membrane filtration technique. Volumes of 10, 100, and $1000 \mu \mathrm{L}$ were filtered through a $0.45-\mu \mathrm{m}$ pore membrane filter, and placed in petri dishes containing Millipore m-ColiBlue24 ${ }^{\circledR}$ broth for coliform and E. coli detection. Plates were placed in an incubator at $35^{\circ} \mathrm{C}$ for 24 hours and were enumerated by counting blue colonies (E. coli) on the filter paper. Colony counts per volume sampled were then converted to counts per dry-weight gram of feces for comparison. Volumes filtered altered with sampling cycle. Early in the experiment when counts were extremely high, only volumes of 10 and $100 \mu \mathrm{L}$ were filtered; later in the experiment, when numbers decreased, larger volumes of water were filtered, up to $2 \mathrm{~mL}$. Triplicate filtrations were performed on approximately $10 \%-15 \%$ of the samples from each sampling run to determine accuracy.

\section{Statistical Design}

The design for this experiment at each sampling time was a splitplot, with shade cloth as the main plot arranged as a completely randomized design, and fecal-pat size and contact (ground or tray) as the split-plot factors. Analysis was conducted at each sampling time using Proc Mixed in SAS ${ }^{\circledR}$ (1996). Fixed effects included shade, pat size, contact, and time. Random effects were plot, and plot $\cdot$ pat size $\cdot$ contact. A variable named TIME was created which represented the day on which the samples were taken. Samples that were taken within 1 day of each other (small fecal pats one day and large fecal pats the next) were grouped. All factors (shade, pat size, contact, and time) were included in the model and comparisons were made with this arrangement of sampling time. The overall analysis with TIME indicated that a 4-way interaction was significant. Therefore, an analysis was performed for each TIME and produced the least-square means for all the effects. The data were also analyzed using a repeated measures model with a $\mathrm{UN}(1)$ variance-covariance structure.
Table 1. Observed significance levels ( $P$-values) for fixed effects for each day ${ }^{1}$ (i.e. TIME) sampled.

\begin{tabular}{lcccccc}
\hline \multicolumn{1}{c}{ Effect } & Day 1 & Day 17 & Day 24 & Day 31 & Day 38 & Day 45 \\
\hline Shade & NS $^{2}$ & 0.07 & 0.008 & 0.057 & 0.0008 & 0.0006 \\
Pat size & NS & $<.0001$ & NS & NS & NS & NS \\
Shade $\cdot$ Pat size & NS & 0.08 & NS & NS & NS & NS \\
Contact & NS & 0.005 & NS & NS & NS & NS \\
Shade $\cdot$ contact & NS & 0.02 & 0.0003 & NS & NS & NS \\
Pat size $\cdot$ contact & NS & NS & 0.02 & NS & NS & NS \\
Shade $\cdot$ Pat $\cdot$ contact & NS & 0.004 & NS & NS & NS & NS
\end{tabular}

${ }^{1}$ Note: On Days 3 and 7 , only the large fecal pats were sampled due to a delay in shipping of laboratory supplies. Data for these days was analyzed separately since we only had 1 fecalpat size (large). There were no significant differences for the shade, and shade $\cdot$ contact effects $(P>0.05)$. On Day 7 , the large fecal pats in contact with the plate had a significantly higher number of colony-forming units $(\mathrm{CFU}) \cdot \mathrm{g}^{-1}$ than did the large fecal pats on the ground $(P=0.03)$.

${ }^{2} \mathrm{NS}=$ not significant, $P>0.1$.

The analysis indicated that the variances among times were not the same, but there was no correlation among times. The results were similar to those obtained with the split-plot analysis, therefore, the data from the split-plot analysis for each TIME is presented.

$\log _{10}$ values were used to perform the statistical analysis because of the large range in data for E. coli concentrations. Percent moisture was added as a covariate to the model; however, the results did not converge. A linear relationship between $\log _{10}$ counts and moisture did not exist or was dependent on treatments only for certain times. It was concluded that moisture was not a very useful covariate.

\section{RESULTS AND DISCUSSION}

The primary objective of this study was to examine the impact of shade (direct solar radiation) on the survival of natural populations of E. coli in beef cattle fecal pats. Beef cattle pats were chosen because ranching and non-point-source pollution by range cattle is often cited as having a negative impact on water quality (Kauffman and Krueger 1984; Belsky et al. 1999). However, most studies investigating fecal pollution and survival of $E$. coli have concentrated on intensive agriculture or manure slurries (Entry et al. 2000a, 2000b; Rosen 2000). This study attempted to characterize what would be closer to reality for a rangeland situation where feces were surface-deposited in smaller pats and not incorporated into the soil. The authors do recognize that blending the manure and making fecal pats is not the same as direct deposit of fecal pats on the land surface. Blending the manure increases aeration, which could impact the survival of E. coli. However, the authors felt that with their experimental design, they could conduct a controlled experiment with replication and minimize the impacts of variables other than those under investigation.

Results show that shade was the only significant factor affecting the survival of E. coli from Day 17 to Day 45 (Table 1). Fecal-pat size and contact (ground or tray) were only significant on Day 17. This was unexpected, as different moisture levels and temperatures between the small and large fecal pats were observed. There was no significant difference in 


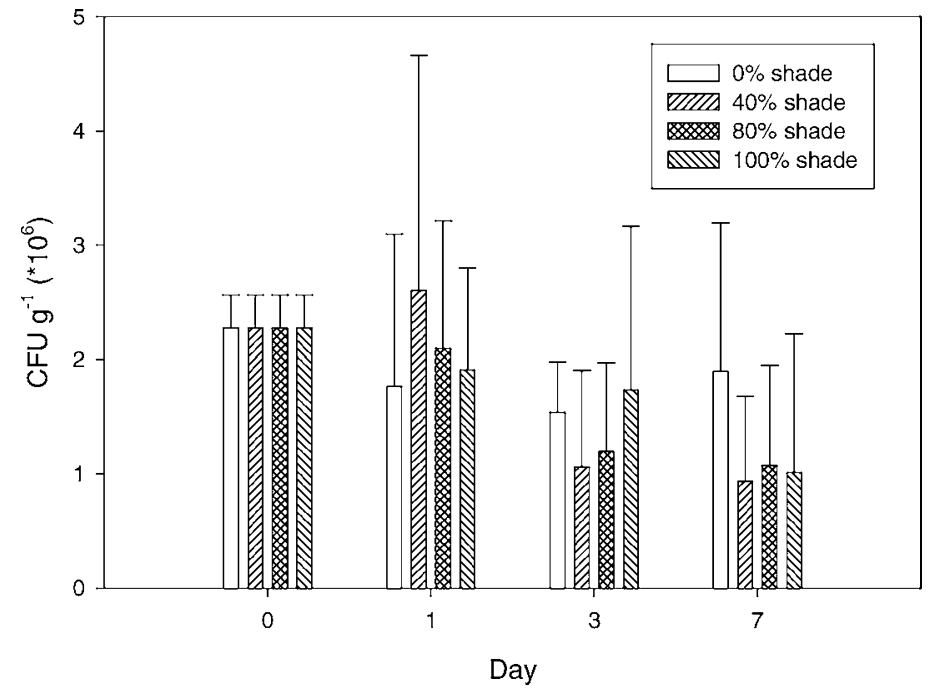

Figure 1. Mean E. coli concentrations (CFU $\cdot \mathrm{g}^{-1}$ dry-weight manure) and SD for large fecal pats for Days $0,1,3$, and 7 . There was no significant difference between shade treatment for each day sampled.

E. coli concentrations under the shade treatments for the large fecal pats for the first week of sampling (Fig. 1). E. coli was able to survive for more than 45 days in the hot, dry summer weather, and shade enhanced the survival of E. coli (Fig. 2). At the end of the experiment, fecal pats under the $0 \%$ and $40 \%$ shade cloth had significantly lower colony-forming units $(\mathrm{CFU}) \cdot \mathrm{g}^{-1}$ compared to those under the $80 \%$ and $100 \%$ treatments.

Percent moisture of feces declined faster under the $0 \%$ shade tarp than under the $100 \%$ shade tarp, but it was not a covariant that could be used to show a strong relationship with E. coli $\mathrm{CFU} \cdot \mathrm{g}^{-1}$ as illustrated in Figure 3. By Day 31 the percent

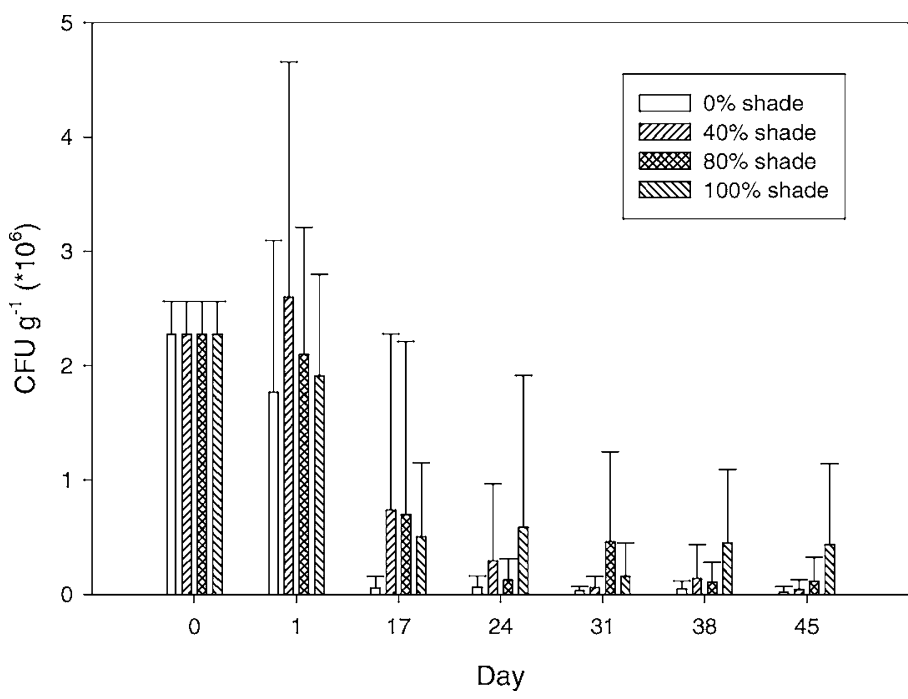

Figure 2. Mean E. coli concentrations (CFU $\cdot \mathrm{g}^{-1}$ dry-weight manure) and SD of all fecal pats for each day (i.e. TIME) and shade treatment. From Day 17 to Day 45, percent shade was significant. Note that results for Days 3 and 7 are not on this figure since only the large fecal pats were sampled (see Fig. 1). Three outliers (Day 1, 40\% shade treatment; Day $24,100 \%$ shade treatment; and Day $31,80 \%$ shade treatment) were removed from the data set.

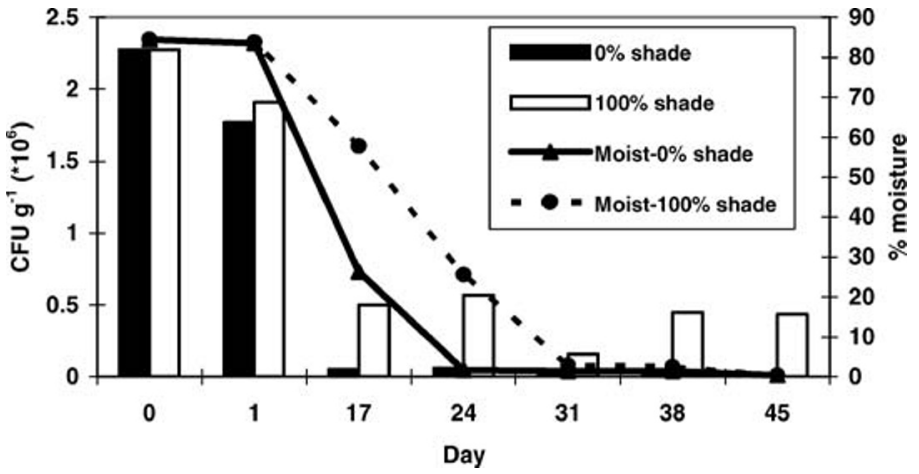

Figure 3. E. coli concentrations (CFU $\cdot \mathrm{g}^{-1}$ dry-weight manure) and percent moisture of feces under the $0 \%$ and $100 \%$ shade tarps. Moist$0 \%$ shade is the percent moisture of feces under the $0 \%$ shade tarp, moist $-100 \%$ shade is the percent moisture of feces under the $100 \%$ shade tarp.

moisture was still declining, whereas E. coli concentration under the $100 \%$ shade treatment was increasing. It was suspected that this is likely due to survival, reproduction, and persistence of several different E. coli strains in the manure. Unc and Goss (2003) suggested that available moisture was the most important factor affecting bacterial survival and should be measured. In our experiment, percent moisture of the feces was measured, but did not show a relationship with bacterial survival.

E. coli levels were observed to increase on Days 1 and 7 under the $40 \%$ and $0 \%$ shade treatments respectively, suggesting that it may be possible for E. coli to replicate in the environment. Previous studies have also suggested that E. coli is capable of replicating in the environment (Gerba and McLeod 1976; Tassoula 1997; Byappanahalli and Fujioka 1998; Topp and Scott 2003; Topp et al. 2003; Unc and Goss 2003). Overall, time and exposure to sunlight had a significant negative impact on the survival of E. coli in beef cattle fecal pats. Further research is needed on the survival and behavior in the environment of E. coli and other fecal bacteria and pathogens from different animal feces. Identifying similarities in survival characteristics in the environment between pathogenic organisms and indicators would also be very useful.

\section{MANAGEMENT IMPLICATIONS}

From a management perspective, E. coli in fecal pats under forested situations would survive longer than in open grasslands due to the shade potential. However, if there was not adequate forage in the denser forested areas, the cattle would spend more time in open areas or areas of available forage. Tate et al. (2003) found that cattle feces distribution patterns were significantly associated with the location of livestock attractants, slope percent and aspect, hydrologic position, and season. By understanding these patterns on different landscapes and using cattle distribution tools, ranchers or land managers can move livestock from areas of high risk to lower-risk areas to minimize or eliminate fecal contamination of water supplies.

E. coli concentrations remained high during the first 7 days of exposure to the environment. However, it is not known what the transport potential of bacteria from the fecal pats would be 
on the different days throughout the study. Fecal pats crust over quickly and begin to dry out and it is not known how much precipitation or what intensity of precipitation would be needed to move the bacteria from the pats into soils or water sources. One would expect that the drier or thicker the fecalpat crust, the more difficult movement of E. coli would become. Therefore, the season of grazing may impact the ability of $E$. coli to move from fecal pats, since in the spring or fall the days are not as hot or dry as in the mid- to late summer.

As indicated earlier, more studies are needed in order to understand both the survival and transport potential of fecal pathogens. Scientific knowledge from experiments directed at the survival and transport can be applied to improve management plans and reduce both the impact of fecal pollution on water quality and the risk to human health.

\section{ACKNOWLEDGMENTS}

Authors wish to thank Terri France, Charmaine Martins, Bruce Roddan, Dr Toby Entz, Dr Dan Durall, Mavis Ulansky, Tom Barker, Fred and Diane Findlay, Coldstream Ranch, and the office staff of the Ministry of Agriculture, Food and Fisheries for their assistance in this project.

\section{LITERATURE CITED}

AleXANDER, M. 1986. Fate and movement of microorganisms in the environment. Part 1: survival and growth of bacteria. Environmental Management 10: 463-469.

Avery, S. M., A. Moore, and M. L. Hutchison. 2004. Fate of Escherichia coli originating from livestock faeces deposited directly onto pasture. Letters In Applied Microbiology 38:355-359.

[B. C. Gov.] British Columbia Government. 2001. A report on the health of British Columbians: Provincial health officer's annual report 2000. Drinking water quality in British Columbia: The public health perspective. Victoria, BC, Canada: Ministry of Health Planning. 147 p. Available at: http://www. healthplanning.gov.bc.ca/pho/. Accessed 5 April 2003.

Belsky, A. J., A. Matzke, and S. Uselman. 1999. Survey of livestock influences on stream and riparian ecosystems in the western United States. Journal of Soil and Water Conservation 54:419-431.

Bohn, C. C., AND J. C. Buckhouse. 1985. Coliforms as an indicator of water quality in wildland streams. Journal of Soil and Water Conservation 40:95-97.

Buckhouse, J. C., AND G. F. GifFord. 1976. Water quality implications of cattle grazing on a semiarid watershed in southeastern Utah. Journal of Range Management 29:109-113.

Byappanahalli, M. N. and R. S. Fujooka. 1998. Evidence that tropical soil environment can support the growth of Escherichia coli. Water Science and Technology 38:171-174.

Chamberlin, C. E., and R. Michell. 1978. A decay model for enteric bacteria in natural waters, In: R. Mitchell [ed.]. Water pollution microbiology. Volume 2. New York: NY: John Wiley \& Sons. p 325-348.

Doyle, R. C., D. C. Wolf, AND D. F. Bezdicek. 1975. Effectiveness of forest buffer strips in improving the water quality of manure polluted runoff. In: Managing Livestock Wastes, Procedures of the Third International Symposium on Livestock Wastes, Proc. 275. St. Joseph, MI: American Society of Agricultural Engineers. p 299-302.

Entry, J. A., R. K. Hubbard, J. E. Thies, and J. J. Fuhrmann. 2000a. The influence of vegetation in riparian filterstrips on coliform bacteria: i. movement and survival in water. Journal of Environmental Quality 29:1206-1214.

Entry, J. A., R. K. Hubbard, J. E. Thies, and J. J. Fuhrmann. 2000b. The influence of vegetation in riparian filterstrips on coliform bacteria: ii. survival in soils. Journal of Environmental Quality 29:1215-1224.

Ferguson, C., A. de Roda Husman, N. Altavilla, D. Deere, and N. Ashbolt. 2003. Fate and transport of surface water pathogens in watersheds. Critical Reviews in Environmental Science and Technology 33(3):299-361.

FuJIOKA, R. S., H. H. НАSHimoto, E. B. Siwak, And H. F. Young. 1981. Effect of sunlight on survival of indicator bacteria in seawater. Applied and Environmental Microbiology 41:690-696.

Gerba, C. P. and J. S. Mcleod. 1976. Effect of sediments on the survival of Escherichia coli in marine waters. Applied and Environmental Microbiology 32:114-120.

Kauffman, J. B., and W. C. Krueger. 1984. Livestock impacts on riparian ecosystems and streamside management implications ... a review. Journal of Range Management 37:430-437.

Larsen, R. E., J. R. Miner, J. C. Buckhouse, and J. A. Moore. 1994. Water quality benefits of having cattle manure deposited away from streams. Bioresource Technology 48:113-118.

Meays, C. L., K. Broersma, R. N. Nordin, and A. Mazumder. 2004. Source tracking fecal bacteria in water: a critical review of current methods. Journal of Environmental Management 73(1):71-79.

Park, R. W. A., P. L. Griffiths, and G. S. Moreno. 1991. Sources and survival of Campylobacters: relevance to enteritis and the food industry. Journal of Applied Bacteriology Symposium Supplement 70:97S-106S.

ROSEN, B. H. 2000. Waterborne pathogens in agricultural watersheds. USDA NRCS Watershed Science Institute. 62 p.

Russell, J. B., F. Diez-Gonzalez, and G. N. Jarvis. 2000a. Potential effect of cattle diets on the transmission of pathogenic Escherichia coli to humans. Microbes and Infection 2:45-53.

Russell, J. B., F. Diez-Gonzalez, and G. N. Jarvis. 2000b. Invited review: effects of diet shifts on Escherichia coli in cattle. Journal of Dairy Science 83:863-873.

SAS INSTITUTE INC. 1996. Selected SAS ${ }^{\circledR}$ documentation: Design and analysis of experiments (spring 1996). Cary, NC: SAS Institute Inc. 496 p.

Scott, T. M., J. B. Rose, T. M. Jenkins, S. R. Farrah, and J. Lukasik. 2002. Microbial source tracking: current methodology and future directions. Applied and Environmental Microbiology 68(12):5796-5803.

Sherr, B. F., E. B. Sherr, and R. D. Fallon. 1987. Use of monodispersed, fluorescently labeled bacteria to estimate in situ protozoan bacterivory. Applied and Environmental Microbiology 53:958-965.

Simpson, J. M., J. W. Santo Domingo, and D. J. Reasoner. 2002. Microbial source tracking: state of the science. Environmental Science Technology 36(24): 5279-5288.

TASsoula, E. A. 1997. Growth possibilities of $E$. coli in natural waters. International Journal of Environmental Studies 52:67-73.

Tate, K. W., E. R. Atwill, N. K. McDougald, and M. R. George. 2003. Spatial and temporal patterns of cattle Feces deposition on rangeland. Journal of Range Management 56:432-438.

Topp, E., AND A. Scott. 2003. Persistence of pathogenic and indicator bacteria in agricultural soils. Proceedings of 2nd Canadian Organic Residuals Recycling Conference. 24-25 April 2003; Penticton, BC, Canada. p. 313-322.

Topp, E., M. Welsh, Y. Tien, A. Dang, G. Lazarovits, K. Conn, and H. Zhu. 2003. Strain-dependent variability in growth and survival of Escherichia coli in agricultural soil. FEMS Microbiology Ecology 44:303-308.

Unc, A., AND M. J. Goss. 2003. Impact of manure properties on the survival of manure Escherichia coli in soils. Proceedings of 2nd Canadian Organic Residuals Recycling Conference. 24-25 April 2003; Penticton, BC, Canada. p. 331-346.

[WHO] World Health Organization. 2003. Emerging Issues in Water and Infectious Disease. Geneva, Switzerland: World Health Organization. 24 p. Available at: http://www.who.int/water_sanitation_health/emerging/emergingissues/en. Accessed 29 October 2003. 